\title{
SPRAWDZONE W UŻYCIU, CZYLI O PODRĘCZNIKACH I OPRACOWANIACH DO NAUCZANIA JEZZYKA POLSKIEGO SPECJALISTYCZNEGO, POWSTAEYCH W CENTRUM JĘZYKA I KULTURY POLSKIEJ W KRAKOWIE
}

Nauczanie języka polskiego w jego odmianach specjalistycznych staje się coraz ważniejszą dziedziną nauczania, ponieważ coraz większa liczba studentów, głównie ze Wschodu (Ukraina, Białoruś) wybiera Polskę na miejsce swoich przyszłych studiów. Tradycje nauczania polskiego do celów edukacyjnych sięgają lat pięćdziesiątych, kiedy to łódzki ośrodek kształcenia cudzoziemców zaczął przygotowywać obcokrajowców do studiów w Polsce. Pierwsze publikacje (skrypty) przeznaczone do nauczania jpjo w odmianach specjalistycznych pojawiły się tam już w latach sześćdziesiątych. Zebrał je i opisał Mieczysław Czernik w „Bibliografii dorobku pracowników Studium Języka Polskiego dla Cudzoziemców Uniwersytetu Łódzkiego” UŁ. Łódź 1988. Aktualnie wszystkie liczące się ośrodki kształcenia cudzoziemców prowadzą nauczanie w zakresie odmian specjalistycznych języka, organizują konferencje poświęcone temu zagadnieniu i wydają tomy pokonferencyjne zawierające teksty opisujące najważniejsze zagadnienia dotyczące tego tematu (np. Metodyka nauczania języka polskiego dla Polaków ze Wschodu i Polonii, J. Mazur (red.), Lublin 1993; „Acta Universitatis Lodziensis. Kształcenie Polonistyczne Cudzoziemców” [Kształcenie specjalistyczne cudzoziemców], nr 7/8, Bożena Ostromęcka-Frączak (red.), Łódź 1996 czy Języki specjalistyczne. Zagadnienia dydaktyki i przekładu P. Mamet, A. Mrózek (red.), Katowice 2003).

Niniejsze opracowanie poświęcone jest pracom teoretycznym i podręcznikom do nauki polszczyzny specjalistycznej, które powstały w Uniwersytecie Jagiellońskim, a konkretnie w Centrum Języka i Kultury Polskiej. W Centrum od wielu lat prowadzone są specjalistyczne kursy dla studentów, którzy zamierzają odbyć swoje studia w Polsce. Aktualnie oferowane są kursy języka medycznego, ekonomii i biznesu, prawa i polityki, a także pisania tekstów dziennikarskich.

\section{OPRACOWANIA TEORETYCZNE}

Literatura przedmiotu (JS) składa się z publikacji teoretycznych i praktycznych materiałów do pracy ze studentami. W ośrodku krakowskim pierwsze teoretyczne rozważania na temat natury języka specjalistycznego i jego glottodydaktycznych implikacji powstały na przełomie lat siedemdziesiątych i osiemdziesiątych a zostały opublikowane w „Przeglądzie Polonijnym”. Były to artykuły:

Danecka-Chwals A., Pukas-Palimąka D., Chłopicka M., 1979, Z zagadnień nauczania odmiany specjalistycznej języków obcych (na przykładzie nauczania języka medycznego studentów polonijnych), „Przegląd Polonijny” V, z. 4, s.73-82, Kraków.

*magda.mays@gmail.com; Centrum Języka i Kultury Polskiej w Świecie, Uniwersytet Jagielloński, ul. Grodzka 64, 32-044 Kraków. 
Danecka-Chwals A., Pukas-Palimąka D., Chłopicka M., 1981, Założenia metodyczne i lingwistyczne podręcznika języka medycznego dla studentów polonijnych, „Przegląd Polonijny” VII, z. 1, s. 57-67, Kraków.

Wymienione artykuły dotyczą refleksji nad założeniami teoretycznymi i metodologicznymi budowy oraz zawartości materiałów do nauczania języka polskiego cudzoziemców, którzy zamierzają studiować medycynę w Polsce. Koncepcje przedstawione przez autorki zostały w późniejszych latach urzeczywistnione w dwóch podręcznikach do nauki języka medycznego - o czym niżej. Warto zaznaczyć, że były to jedne z pierwszych opracowań opisujących cechy charakterystyczne języka specjalistycznego oraz sugerujących budowę podręcznika ukierunkowanego na potrzeby konkretnego odbiorcy.

Śliwiński W., 1985, Podstawy metodologiczne i dydaktyczne podręcznika języka polskiego dla humanistów, „Przegląd Polonijny”, z. 4 s.107-118.

Artykuł zawiera rozważania na temat pojęcia ,język humanistyczny" i jego miejsca w dydaktyce. Następnie autor opisuje cele i założenia podręcznika dla humanistów uczących się języka polskiego jako obcego. W dalszej części publikacji znajduje się szczegółowy opis zawartości przygotowywanego podręcznika: jego budowy oraz proponowanych treści. Zadaniem podręcznika - w zamyśle autora - jest przygotowanie cudzoziemca do studiów filologicznych.

Chłopicka M., Pukas-Palimaka D., 1988, Założenia lingwistyczne i metodyczne drugiej części podręcznika języka medycznego dla studentów polonijnych, „Przegląd Polonijny” z. 2, s. 119-129.

Artykuł poświęcony jest opisowi zawartości powstającej wówczas drugiej części podręcznika do języka medycznego pt. Co panu dolega? Podstawowe założenia metodyczne zakładały oparcie się na metodzie komunikacyjnej i przygotowanie przyszłych studentów medycyny do kontaktu z pacjentem. Zwrócono tutaj uwagę na rangę funkcji językowych, służących do nawiązywania i podtrzymywania kontaktu językowego.

Chłopicka-Wielgos M., Pukas-Palimąka D., 1996, Nauczanie języka specjalistycznego a nie tylko terminologii, w: „Acta Universitatis Lodziensis. Kształcenie Polonistyczne Cudzoziemców” [Kształcenie specjalistyczne cudzoziemców], nr 7/8, Łódź 1996.

W pierwszej części publikacji autorki podają charakterystykę stylu naukowego oraz przegląd literatury na ten temat. Następna część poświęcona jest rozważaniom nad sposobami i metodami nauczania języka i terminologii medycznej.

Artykuł jest podsumowaniem doświadczeń z pracy autorek z podręcznikami do nauczania języka medycznego. 
Bardzo ważna dla Centrum teoretyczna publikacja ukazała się w 2012 r. i była to książka:

Ligara B., Szupelak W., 2012, Lingwistyka i glottodydaktyka języków specjalistycznych na przykładzie języka biznesu. Podejście porównawcze, Kraków.

Opracowanie składa się z dwóch części: pierwszej, teoretycznej i drugiej, nawiązującej do praktyki nauczania języka biznesu w ujęciu porównawczym (angielski i polski). W części teoretycznej B. Ligara prezentuje „zbiorczy stan badań nad dydaktyką języka specjalistycznego” (Wstęp, Miodunka) a w części drugiej W. Szupelak zajmuje się wszelkimi aspektami metodyki nauczania języka biznesu. W pierwszych sześciu rozdziałach B. Ligara referuje pojęcia i definicje występujące w języku specjalistycznym w różnych ujęciach: polonistycznym, językoznawczym, glottodydaktycznym. Rozdziały od 6 do 13 zawierają charakterystykę uczących się języka biznesu, przegląd podręczników oraz m.in. treści i metod nauczania języka obcego dla celów biznesowych. W zakończeniu zamieszczono przykładowe scenariusze zajęć.

W 2016 r. powstał artykuł autorstwa P. E. Gębala i S. Kołsut pt. Nauczanie języka polskiego dla potrzeb zawodowych. Profile kompetencji językowych w komunikacji specjalistycznej (w druku).

Artykuł dotyczy „,badań potrzeb językowych w zakresie komunikacji w środowiskach zawodowych", jak pisze autor, który brał udział w międzynarodowym projekcie badawczym JASNE - Alles klar! (Projekt opisany w publikacji: Profile kompetencji językowych w komunikacji zawodowej. JASNE -Alles klar!, 2015, Dresden). W artykule znajduje się opis tego, jak przeprowadzono badania i opracowano profile kompetencji językowych w komunikacji zawodowej. Artykuł ukaże się w tomie pod red. I. Janowskiej i P. Gębala, a zatytułowanym O lepsze jutro studiów polonistycznych w świecie. Glottodydaktyka polonistyczna dziś, 2016, Kraków.

\section{SPECJALISTYCZNY JĘZYK POLSKI DLA CUDZOZIEMCÓW. PODRĘCZNIKI I POMOCE}

\section{Język medyczny}

Danecka-Chwals A., Chłopicka M., Pukas-Palimąka D., 1986, O człowieku po polsku. Podręcznik języka medycznego dla obcokrajowców, Kraków.

Podręcznik składa się z trzech części: 25 tematów dotyczących anatomii i funkcjonowania poszczególnych układów w ciele człowieka, słownika polsko-angielskiego z objaśnieniami gramatycznymi i wyboru tekstów uzupełniających do tematów zawartych w części pierwszej. W książce są rysunki i tablice poglądowe o tematyce medycznej. Mimo upływu lat od wydania pozycji - podręcznik jest nadal w użyciu w częściach lub wybranych fragmentach.

Chłopicka M., Pukas-Palimąka D., Turek-Fornelska K., 1991, Co panu dolega? Komunikacyjny podręcznik języka medycznego dla cudzoziemców, Kraków. 
Podręcznik został napisany jako dopełnienie części pierwszej, czyli $O$ człowieku po polsku i oparty jest na metodzie komunikacyjnej, a więc koncentruje się na używaniu języka mówionego (tzw. funkcji językowych) w pracy lekarza. Nie ma tu thumaczeń angielskich, a tekst uzupełniony jest ilustracjami czarno-białymi. Publikacja zawiera wiele przykładów autentycznych dokumentów służących do ewidencjonowania badań lekarskich i nadal pozostaje w użyciu na zajęciach z języka medycznego.

Obydwie książki zostały wydane w tzw. „Zielonej” serii, w czarno-białej oprawie graficznej, niestety nie przystającej do dzisiejszych standardów.

Chłopicka-Wielgos M., Pukas-Palimąka D., Turek-Fornelska K., 2015, Co panu dolega?, wyd. zmienione, Kraków.

Nowe i zmienione wydanie podręcznika do języka medycznego, oparte na podejściu zadaniowym. Podręcznikowi zapewniono niezwykle atrakcyjną oprawę graficzną. Poszczególne części jednostek lekcyjnych oznaczone są kolorami, zamieszczono wiele nowych zadań do tekstu i zdjęć ilustrujących autentyczne sytuacje w przychodni i szpitalu. Zachowane zostały tematy lekcyjne z poprzedniego wydania, ale uzupełnione zostały nowymi ćwiczeniami słownikowymi oraz ćwiczeniami do rozumienia ze słuchu. Do podręcznika zostały dołączone nagrania tekstów na płycie CD służące do ćwiczeń na rozumienie tekstów mówionych.

Język ekonomiczny

Szelc-Mays M., Długosz P., 1999, O ekonomii po polsku. Podręcznik języka polskiego dla cudzoziemców. Poziom średniozaawansowany, Kraków.

Podręcznik został przygotowany dla studentów obcokrajowców, którzy chcą studiować w Polsce kierunki związane z ekonomią. Zawiera tematykę (szesnaście zagadnień) i słownictwo spotykane w podręcznikach, jakie funkcjonowały w polskich ekonomicznych szkołach średnich, np.: Ekonomia, przedmiot i podstawowe pojęcia, Budżet państwa lub Pieniądz i jego funkcje. Do tekstów przygotowano wiele ćwiczeń na ich zrozumienie oraz oparzono je dodatkowymi ćwiczeniami na utrwalanie słownictwa i terminologii ekonomicznej. Mimo że podręcznik wydany został już dawno, to z powodu treści (niezmienne pojęcia ekonomiczne) nadal jest używany. Autorzy mają nadzieję, że zwiększająca się liczba studentów zainteresowanych nauką języka ekonomicznego pozwoli na wydanie nowej wersji podręcznika.

Język techniczny

Dębski R., Gałdyn E., Szelc-Mays M., 1993, A jednak się kręci. Podręcznik do języka naukowo-technicznego dla cudzoziemców, Kraków. 
Podręcznik składa się z piętnastu lekcji zawierających autentyczne teksty pochodzące z pism naukowo-technicznych, ćwiczeń na rozumienie tekstu i zadań związanych z programem gramatyki przewidywanym dla poziomu średniozaawansowanego. Wśród tematów ujętych w książce są takie jak: Zastosowanie komputerów, Elementy budynków i ich funkcje czy Historie pojazdów samochodowych. Do tekstów dołączony jest zestaw czarno-białych ilustracji. Aktualnie podręcznik bywa używany jako materiał dodatkowy dla kandydatów na wyższe studia techniczne w Krakowie i sprawdza się jako materiał do rozwijania sprawności rozumienia tekstu pisanego.

Język humanistyczny

Śliwiński W., 1986, To właśnie Polska. Podręcznik języka polskiego dla humanistów. Kurs dla zaawansowanych, cz. I, Kraków.

Podręcznik składa się z piętnastu jednostek lekcyjnych nazwanych ,zagadnieniami”. Każde zagadnienie zawiera ćwiczenia propedeutyczne, czyli przygotowujące do czytania tekstu, tekst podstawowy, komentarz gramatyczny oraz ćwiczenia gramatyczno-stylistyczne. Tematyka tekstów związana jest z tzw. kulturą wysoką, czyli dotyczy ważniejszych zagadnień w kulturze polskiej, takich jak: Konkurs Chopinowski, teatr Kantora i Grotowskiego, fragmentów pism Gombrowicza czy Iwaszkiewicza. Jak widać tematyka wybranych przez autora tekstów nie jest przeznaczona dla przeciętnego studenta, ale dla osób zainteresowanych problemami polonistycznymi. Książka wydana jest w tzw. „Zielonej serii”, która ukazywała się w latach osiemdziesiątych ubiegłego wieku i nie jest, niestety, atrakcyjna pod względem wydawniczym. Podręcznik nie miał wielkiego powodzenia z powodu wysokiego stopnia trudności oraz specyficznej tematyki.

Ligara B., 1990, Randez-vous z kultura polską. Podręcznik języka polskiego dla humanistów. Kurs dla zaawansowanych, cz. II, Kraków.

Skrypt ten powstał jako uzupełnienie i część druga podręcznika autorstwa W. Śliwińskiego. Budowa jednostki lekcyjnej jest analogiczna jak w części pierwszej. Podręcznik zawiera dwanaście tematów poświęconych tekstom literackim (M. Białoszewski, S. Mrożek) oraz tekstom historycznym, naukowym i dotyczącym sztuki (malarstwo, rzeźba). Tak jak i w części pierwszej tematyka oraz sposób opracowania materiału jest bardzo specjalistyczny, przeznaczony nie dla typowego studenta, a dla zaangażowanego polonisty. Książka wydana w tzw. „Zielonej serii” jest mało atrakcyjna graficznie.

Mędak S., 2007, W świecie polszczyzny. Podręcznik do nauczania języka polskiego dla obcokrajowców. Poziom C2 - dla zaawansowanych, Kielce

Podręcznik przeznaczony jest dla studentów na poziomie C2, czyli osób z bardzo zaawansowaną znajomością polszczyzny. Składa się z trzydziestu jednostek lekcyjnych, w których znajdują się teksty autentyczne o literaturze i kulturze polskiej, ćwiczenia do rozwijania sprawności językowych 
oraz dział poświęcony gramatyce. Teksty pochodzą ze współczesnych czasopism oraz z Internetu. W części poświęconej rozwijaniu sprawności znajdują się ćwiczenia zawierające różnorodne formy zadań pisemnych i na rozumienie ze słuchu (autor odsyła czytającego do słuchowisk radiowych). Dział gramatyczny zawiera zagadnienia językowe o wysokim stopniu trudności, wiele wyjątków i osobliwości, a także reguł funkcjonujących w języku polskim. Teksty poświęcone są wielkim pisarzom i uczonym polskim, a także znanym osobistościom ze świata polityki, np. L. Balcerowiczowi czy artystom - O. Boznańskiej. Część druga - sprawnościowa - ma bardzo starannie opracowaną część słownikową o nazwie Mały skarbiec polszczyzny, definiowanie wyrazów, pojęć. Podręcznik opatrzony jest indeksami skrótów, zagadnień omawianych w książce oraz bibliografią użytych lub cytowanych tekstów. Dołączona jest płyta CD z ćwiczeniami w liczbie 200.

Mędak S., 2016, Język polski z mistrzami słowa, Kraków.

Podręcznik składa się z dziesięciu jednostek lekcyjnych, z których każda ma sześć zasadniczych części: W tekście i poza tekstem, Wokót gramatyki i składni, Informacje uzupetniające, Sprawności językowe, Wokót stownictwa i frazeologii, Praca samodzielna. Pomoc przeznaczona jest dla studentów uczących się na poziomach B2 i C1. W części tekstowej znajdują się fragmenty prozy autorstwa Sienkiewicza, Gombrowicza, Newerlego, Tyrmanda oraz innych znanych pisarzy, których powieści zostały nagrane w formie e-booków. Do tej formy odwołuje się autor, kiedy mówi o ćwiczeniach na rozumienie tekstu mówionego. W kolejnych częściach książki znajdują się ćwiczenia, których zadaniem jest rozwijanie pozostałych sprawności oraz opanowanie osobliwości gramatyki polskiej.

Podręczniki do nauczania kultury

M. Szelc-Mays, 2003, Tańce malowane. Podręcznik dla dzieci w wieku przedszkolnymi wczesnoszkolnym, Kraków.

Podręcznik ma podtytuł informujący, że jest on przeznaczony dla dzieci, ale spełnia swoją funkcję także wśród dorosłych studentów, którzy chętnie słuchają nagrań przygotowanych na płycie CD i chętnie biorą udział w nauce polskich tańców ludowych. Podręcznik składa się z dwóch części: tekstów piosenek ludowych i malowanek przedstawiających polskie stroje ludowe oraz z propozycji wykorzystania materiałów zebranych w książce do omawiania specyfiki tańców polskich i nauki podstawowych kroków. Do książki dołączona jest płyta CD i zestaw kart z ilustracjami strojów ludowych do gry w „Piotrusia”.

M. Szelc-Mays, 2010, Witamy na Podkarpaciu!, Rzeszów.

Podręcznik został napisany specjalnie dla studentów z Ukrainy i Białorusi, którzy przyjeżdżają na studia do Rzeszowa. Wydany przez stowarzyszenie Absolwent, za pieniądze z Unii Europejskiej, jest rozdawany za darmo studentom. $Z$ tego powodu podręcznik nie jest ogólnodostępny, spotkać go 
można w bibliotekach. Napisany został przy wykorzystaniu założeń metody zwanej CLIL (Content and Language Integrated Learning), polegającej na nauczaniu języka poprzez dostarczanie wiedzy na konkretny temat. W tym wypadku jest to geografia, gospodarka oraz kultura Podkarpacia. Ponieważ w krakowskim Centrum Języka i Kultury Polskiej z roku na rok przybywa studentów ze Wschodu, a szczególnie z Ukrainy, to podręcznik ma zastosowanie przy omawianiu np. mniejszości etnicznych na terenie Polski południowej. W książce są rozdziały opisujące związki Polski z Ukrainą.

\section{PODSUMOWANIE}

Od lat osiemdziesiątych ubiegłego wieku prowadzone są w krakowskim Centrum Języka i Kultury Polskiej (dawniej był to Instytut Polonijny) kursy i zajęcia poświęcone przygotowaniu studentów obcokrajowców do wybranych przez siebie studiów w naszym kraju. Programy i treści nauczania z czasem ulegały modyfikacjom i były przystosowywane do potrzeb studentów (anglojęzycznych lub pochodzących ze Wschodu). Specjalnie dla studentów Centrum opracowano 11 podręczników do nauczania różnych odmian języka polskiego specjalistycznego. Powstało także kilka artykułów teoretycznych zawierających podstawowe założenia językoznawcze i metodyczne do nauczania JS. W 2012 r. ukazała się obszerna monografia ( B. Ligara i W. Szupelak) na temat lingwistycznych i glottodydaktycznych implikacji nauczania języków specjalistycznych. Aktualnie przygotowywane są materiały do kolejnych kursów specjalistycznych. 